\title{
Polish version of Centre for Epidemiological Studies Depression Scale (CES-D): results of a preliminary study on the psychometric properties of the scale
}

\author{
Michat Ziarko ${ }^{A, B, C, D, E, F, G}$, tukasz D. Kaczmarek $^{A, B, C, E, G}$, Piotr Hatadziński ${ }^{C, D, E}$ \\ Adam Mickiewicz University in Poznan, Poland
}

BACKGROUND

The Centre for Epidemiological Studies Depression Scale (CES-D) is one of the most popular diagnostic tools used to assess depression symptoms, both in epidemiological studies and other types of research projects. The aim of the presented study was the assessment of the psychometric qualities of the Polish version of the scale.

\section{PARTICIPANTS AND PROCEDURE}

The study was conducted on a group of patients suffering from a somatic illness and at risk of developing depression $(n=826)$ and among healthy individuals from the general population $(n=1160)$.
RESULTS

The results confirmed the factorial structure of the questionnaire. Convergent validity was confirmed by correlations with other measures of affect and resources consistent with the theory.

\section{CONCLUSIONS}

The results of our analyses confirmed that the Polish version of the questionnaire is satisfactory in terms of construct and criterion validity and provides a reliable psychometric tool.

KEY WORDS

depression; scale; psychometric properties

CORResPonding AUthor - Michał Ziarko, Instytut Psychologii UAM, 9 Szamarzewskiego Str., 60-658 Poznan, Poland, e-mail: ziarko@amu.edu.pl

AUthors' Contribution - A: Study design - B: Data collection - C: Statistical analysis - D: Data interpretation . E: Manuscript preparation - F: Literature search · G: Funds collection

TO CITE THIS ARTICLE - Ziarko, M., Kaczmarek, Ł.D. \& Haładziński, P. (2013). Polish version of Centre for Epidemiological Studies Depression Scale (CES-D): results of a preliminary study on the psychometric properties of the scale. Current Issues in Personality Psychology, 1, 51-61. 


\section{BACKGROUND}

Depression is the most common mental disorder (Seligman, Walter \& Rosenhan, 2003). According to American data, $9.5 \%$ of the population suffers from a depressive disorder (National Institute of Mental Health, 2009). Experiencing its symptoms is treated as a serious mental health problem affecting various populations. Its high severity is observed among elderly people, adolescents and patients with somatic illnesses. Depression symptoms include: persistent depressed mood, lack of interest and pleasure related to everyday activities, weight change (decrease or increase), insomnia, agitation or psychomotor inhibition, feelings of fatigue or loss of energy, feelings of worthlessness, unwarranted guilt, a decline in thinking ability and concentration and recurrent thoughts about death (Seligman et al., 2003). Clinical trials conducted on patients suffering from somatic illnesses revealed that this population has significantly elevated risk of developing depressive disorders. It is estimated that this type of disorder affects $14 \%$ to $27 \%$ of patients suffering from ischaemic heart disease (Shnek, Irvine, Stewart \& Abbey, 2001). This percentage increases among hospitalized patients, especially in the period before surgery, to as much as $30.9 \%$ (Lane et al., 2002). Significantly higher numbers of patients experiencing depressive symptoms suffer at the same time from diagnosed rheumatoid arthritis. Depending on the method used, it is estimated that from $17 \%$ to $62 \%$ of patients with this condition complain about depressive symptoms (Katz \& Yelin, 1993; Uguz, Akman, Kucuksarac \& Tufekci, 2009).

The results of studies on the consequences of experiencing depressive symptoms among patients with rheumatoid arthritis suggest that individuals characterized by extensive symptoms of depression are more likely to experience recurring severe pain (Affleck, Tennen, Urrows \& Higgins, 1991; Zautra \& Smith, 2001; Zautra et al., 2007). Furthermore, experiencing severe symptoms of depression makes it difficult to adapt and live with the disease, which manifests itself by frequent hospitalizations and medical appointments (Fifield et al., 2004).

Another population at risk of developing depression are adolescents and young adults. It is estimated that this problem affects about $15 \%$ of people in this age group (Thapar, Collishaw, Pine \& Thapar, 2012; Kessler, Avenevoli \& Merikangas, 2001), with girls twice as likely as boys (Moses, Warchol-Biederman \& Samborski, 2012; Hankin, Wetter \& Cheely, 2008). The first depressive episodes occur most often between 12 and 18 years of age, and the peak incidence is between 15 and 18 years old (Thapar et al., 2012; Maughan, Collishaw \& Stringaris, 2013). The occurrence of depressive episodes in this stage of life is a serious threat to health because they usually recur in adulthood (Aronen \& Soininen, 2000).
Prevalence of depression and risks associated with it enforce the development of good tools for screening, which allows fast and cheap recognition of individuals at risk of this disorder. There are many tools to measure the level of depression. Shaver and Brennan (1991) present 9 tools used to assess the severity of depression in a compendium presenting an overview of methods used in psychology of personality and cognitive psychology. One of them - the Depression Scale CES-D (Radloff, 1977) - is worth discussing in more detail. It is a popular questionnaire, used to estimate the level of depression in clinical trials and epidemiological studies (Radloff, 1977). Unlike other tools for measuring depression (e.g. the Beck Depression Questionnaire), it is free of charge. This contributes to its widespread use (Hicks \& McCord, 2012) and the collection of a lot of data from different populations (in terms of age, race and problem area), which proves its usefulness (Thomas \& Brantley, 2004).

The Depression Scale CES-D was designed in order to assess the cognitive (negative assessment of various spheres of life), affective (sadness, despondence, feeling of guilt, worthlessness, hopelessness) and somatic (loss of appetite, sleep disorders, psychomotor slowdown) symptoms of depression. Based on the study results, four subscales were differentiated, used to measure the following: (1) depressive affect, (2) lack of positive affect, (3) somatic symptoms and inhibition of activity, and (4) attitude to other people (Radloff, 1977). Meta-analyses of studies using the Depression Scale CES-D confirmed the 4-factor structure of the questionnaire suggested by Radloff (Shafer, 2006). Nevertheless, cultural differences were reported in terms of the contribution of individual factors to the overall result (Kim, DeCoster, Huang \& Chiriboga, 2011). It should be noted that this method is not suitable for the recognition of clinical depression. It was created in order to determine the number and intensity of depressive symptoms when this condition has already been recognized (Seligman et al., 2003; Al-Modallal, 2010).

The aim of this study was to determine the psychometric properties of the Polish adaptation of the CES-D scale (Kaniasty, 2003). To achieve this, concordance of the factor structure of the scale with the theoretical assumptions was investigated (Paterson, O’Rourke, Elmer Shapiro \& Thornton, 2011), relations with other constructs were determined and the reliability of the scale and subscales was assessed.

\section{PARTICIPANTS AND PROCEDURE}

\section{PARTICIPANTS}

The study involved 1986 participants. The sample included both healthy individuals $(n=1160 ; 58.4 \%)$ and those suffering from chronic illnesses $(n=826 ; 41.6 \%)$. 
The group of ill individuals included patients with diagnosed diabetes type I ( $n=229 ; 11.5 \%)$, ischaemic heart disease $(n=208,10.5 \%)$, rheumatoid arthritis $(n=210,10.6 \%)$ and breast cancer $(n=179,9 \%)$. The age of the respondents ranged from 18 to 86 years $(M=35.50, S D=16.57)$. The healthy respondents were younger than the chronically ill ones $(M c=47.52$; $S D_{C}=16.19 ; M_{Z}=26.97, S D z=10.41, t=31.910$, $d f=1288.055, p<0.001)$. This difference is due to the fact that the majority of chronic diseases are diagnosed in patients over forty years of age, and their number increases with age. The sample consisted of 1375 women (69.2\%). Subgroups of ill and healthy individuals differed from each other in terms of gen$\operatorname{der}\left(\chi^{2}(1)=9.678, p=0.002\right)$. More male respondents (46.9\%) suffered from chronic diseases compared to women (39.4\%).

\section{PROCEDURE}

Studies on the population of chronically ill patients were conducted in the event of a health crisis and hospitalisation related to it. The patients included individuals who suffered from ischaemic heart disease and stayed at the Cardiac Rehabilitation Ward of the Provincial Hospital in Poznań after a heart attack; those with diabetes type I and with rheumatoid arthritis. Patients with rheumatoid arthritis were undergoing subsequent relapse and were hospitalised at the Rheumatology and Osteoporosis Ward of J. Struś Hospital in Poznań, at the Orthopaedics-Rehabilitation Ward of W. Dega Hospital in Poznan and the Rheumatology and Rehabilitation Ward with Daily Rehabilitation of the Autonomous Public Provincial Hospital in Szczecin. Diabetic patients were hospitalised at the Diabetology and Internal Diseases Ward of F. Raszeja Hospital in Poznań in connection with unregulated blood sugar or hyperglycaemia, or immediately after the diagnosis of diabetes ${ }^{1}$ The study was longitudinal; patients filled in the research tools twice at an interval of three months - at the beginning of hospitalization and three months after its completion.

Healthy individuals participated in a study investigating well-being in the general population ${ }^{2}$ (Kaczmarek \& Aleszczyk, 2013; Kaczmarek et al., 2013) and in a study on the dietary habits of people in different stages of life.

\section{TOOLS}

The Depression Scale CES-D (Radloff, 1977; Kaniasty, 2003). This scale consists of 20 statements that measure the frequency of depressive symptoms experienced in the past week. The statements relate to depressed mood, feelings of guilt and hopelessness, psychomotor slowdown, sleep disorders (e.g. 'I didn't want to eat, I didn't have appetite'). Answers are provided on a four-point scale, the extremes of which are described as follows: 0 - rarely, or not at all (less than one day); 3 - most of the time or all the time (5-7 days). The overall result is the sum of all responses, which ranges from 0 to 60 points. A higher score indicates a higher level of depression, and it is recognized that the level of 16 points distinguishes people who do not manifest symptoms of depression from those who demonstrate them (Craig \& Van Natta, 1978; Andresen, Malmgren, Carter \& Patrick, 1994). Results below 16 points indicate the absence of symptoms of depression, in the range of 16-26 points suggest moderate depression, and more than 27 points indicate deep depression (Zich, Attkisson \& Greenfield, 1990). In this study a translation of the scale into Polish was used, as prepared by Kaniasty (2003).

Factor analysis allows differentiation of four independent dimensions forming the CES-D scale. These are as follows: depressive affect (7 test items), absence of well-being (4 items), somatic symptoms (7 items) and interpersonal affect (2 items) (Paterson et al., 2011).

In order to validate the tools used in the study, a number of well-being measures were included, related to the following: negative habitual thinking, sense of satisfaction with life, sense of coherence, social support, psychological resilience, self-efficacy and acceptance of the disease. Psychometric information regarding these tools is presented in Table 1.

\section{RESULTS}

\section{DESCRIPTIVE STATISTICS AND THE RELIABILITY OF THE TOOL}

Table 2 shows the descriptive statistics for the CES-D questionnaire and its subscales for healthy individuals, patients and the whole investigated sample.

Construct validity. To determine the factor validity of the tools, confirmatory factor analysis was performed using the statistical package LISREL 8.8 (Jöreskog \& Sörbom, 2006). In order to test the assumed structural and measurement model, confirmatory factor analysis was performed separately for the group of healthy individuals $(n=1160)$ and patients $(n=826)$. Satorra-Bentler adjustment was applied to the $\chi^{2}$ test (Satorra \& Bentler, 1988). In order to interpret the goodness of fit of the data to the mod$\mathrm{el}$, the following indices were used: goodness-of-fit index (GFI), adjusted goodness-of-fit index (AGFI), comparative fit index (CFI) and the root mean square error of approximation (RMSEA). The goodness of fit of the model is indicated by the following criteria: GFI $>0.95$, AGFI $>0.90$ and RMSEA $<0.05(\mathrm{Hu} \&$ Bentler, 1998; Marsh, Hau \& Wen, 2004). The value of the CFI factor indicating a good fit should be higher than 0.97 , but it is assumed that values between 
Table 1

Descriptive statistics and reliability indicators for tools used to validate the CES-D scale

\begin{tabular}{|c|c|c|c|c|c|c|c|}
\hline Name of the tool & $\begin{array}{l}\text { No. of } \\
\text { items }\end{array}$ & $\begin{array}{l}\text { Scale } \\
\text { span }\end{array}$ & Min & Max & M & $S D$ & $\begin{array}{l}\text { Cron- } \\
\text { bach's } \alpha\end{array}$ \\
\hline $\begin{array}{l}\text { Anxious Thoughts Inventory (AnTI) } \\
\text { (Wells, 1994) }\end{array}$ & 22 & $22-88$ & 0.00 & 80.61 & 39.43 & 11.43 & 0.94 \\
\hline $\begin{array}{l}\text { Acceptance of the disease Scale (AIS) } \\
\text { (Felton, Revenson \& Hinrichsen, 1984; } \\
\text { Polish adaptation: Juczyński, 2001) }\end{array}$ & 8 & $8-40$ & 5.00 & 35.00 & 21.12 & 5.79 & 0.82 \\
\hline $\begin{array}{c}\text { Satisfaction with Life Scale (SWLS) } \\
\text { (Diener, Emmons, Larsen \& Griffin, } \\
\text { 1985; Polish adaptation: } \\
\text { Juczyński, 2001) }\end{array}$ & 4 & $1-35$ & 8.00 & 40.00 & 25.15 & 7.06 & 0.81 \\
\hline Social Support Scale (Gärtner, 2006) & 14 & $14-70$ & 14.00 & 70.00 & 57.45 & 10.20 & 0.92 \\
\hline $\begin{array}{l}\text { Life Orientation Questionnaire - } \\
\quad \text { SOC } 29 \text { (Antonovski, 1995) }\end{array}$ & 29 & $29-203$ & 55.00 & 201.00 & 129.11 & 22.31 & 0.84 \\
\hline $\begin{array}{c}\text { General Self-Efficacy Scale (Schwarzer } \\
\& \text { Jerusalem, 1995; Polish adaptation: } \\
\text { Juczyński, 2001) }\end{array}$ & 10 & $10-40$ & 10.00 & 40.00 & 30.11 & 4.89 & 0.88 \\
\hline $\begin{array}{l}\text { The Ego Resiliency Scale ER89 (Block } \\
\text { \& Kremen, 1996; Polish adaptation: } \\
\text { Kaczmarek, 2011) }\end{array}$ & 14 & $14-56$ & 16.00 & 56.00 & 41.51 & 7.07 & 0.85 \\
\hline
\end{tabular}

0.95 and 0.97 are also acceptable (Schermelleh-Engel, Moosbrugger \& Muller, 2003).

The confirmatory factor analysis conducted in the group of healthy individuals confirmed the four-factor hierarchical structure of the questionnaire (depressive mood, well-being, somatic symptoms and attitude to other people) with the higher order factor - depression. Model parameters confirm its goodness of fit: S-B $\chi^{2}=1075.03 ; d f=166 ; p<0.01$; GFI = 0.99; $\mathrm{AGFI}=0.98$; $\mathrm{CFI}=0.98$; RMSEA $=0.069$; RMSEA $95 \%$ CI [0.065; 0.073]. Factor loadings in the measurement model ranged from 0.70 to 0.89 for the depressive mood, 0.44 to 0.89 for well-being, 0.5 to 0.81 for somatic symptoms and 0.65 to 0.93 for attitude to others. In the structural model the factor loadings ranged from 0.72 to 0.99 (Fig. 1).

Conclusions in the group of patients were similar; the four-factor structure of the questionnaire was also confirmed (depressive mood, well-being, somatic symptoms and attitude to other people) with the higher-order factor - depression. The model parameters were similar to the results obtained in the group of healthy individuals. They confirm the good fit of the model to the empirical data: S-B $\chi^{2}=911.74 ; d f=$ $=167 ; p<0.01 ; \mathrm{GFI}=0.99 ; \mathrm{AGFI}=0.98 ; \mathrm{CFI}=0.98$; RMSEA $=0.074$; RMSEA 95\% CI $[0.069 ; 0.078]$. Factor loadings ranged from 0.74 to 0.88 for the depressive mood, 0.29 to 1.00 for well-being, 0.60 to 0.80 for somatic symptoms and 0.63 to 0.91 for attitude to others. In the structural model the factor loadings ranged from 0.78 to 0.99 (Figure 2).

These analyses were followed by a test for whether the measurement model and factor loadings were fixed for both groups (Du Toit \& Du Toit, 2001; Jöreskog \& Sörbom, 1999).

In order to verify whether the measurement model is fixed for both sample groups, two hypotheses were tested: $H_{0}$ concerning the fixed effect model for both groups and $H_{1}$ assuming that the model differs between the groups. The $\chi^{2}$ test was used to test the hypotheses: $\chi_{0}^{2}=5180.46 ; d f=376 ; p<0.001 ; \chi_{1}^{2}=4720.47 ; d f=336$; $p<0.001 ; \Delta \chi^{2}=459.99 ; \Delta d f=40 ; p<0.001$. The obtained solution indicates that the measurement model is fixed for both groups.

The $\chi^{2}$ test was also used to check whether the factor loadings are fixed: $\chi_{0}^{2}=5043.77 ; d f=356 ; p<0.001$; $\chi^{2}{ }_{1}=4720.47 ; d f=336 ; p<0.001 ; \Delta \chi^{2}=323.3 ; \Delta d f=$ $=20 ; p<0.001$. Based on the obtained solution, it can be concluded that the factor loadings are the same for both groups.

Temporal stability. In order to assess the temporal stability of the tool, two measurements were taken three months apart in the group of healthy $(n=318)$ and ill $(n=596)$ individuals. The correlation between the measurements for the whole questionnaire was high, $r=0.73, p<0.001, n=914$, for a subgroup of 


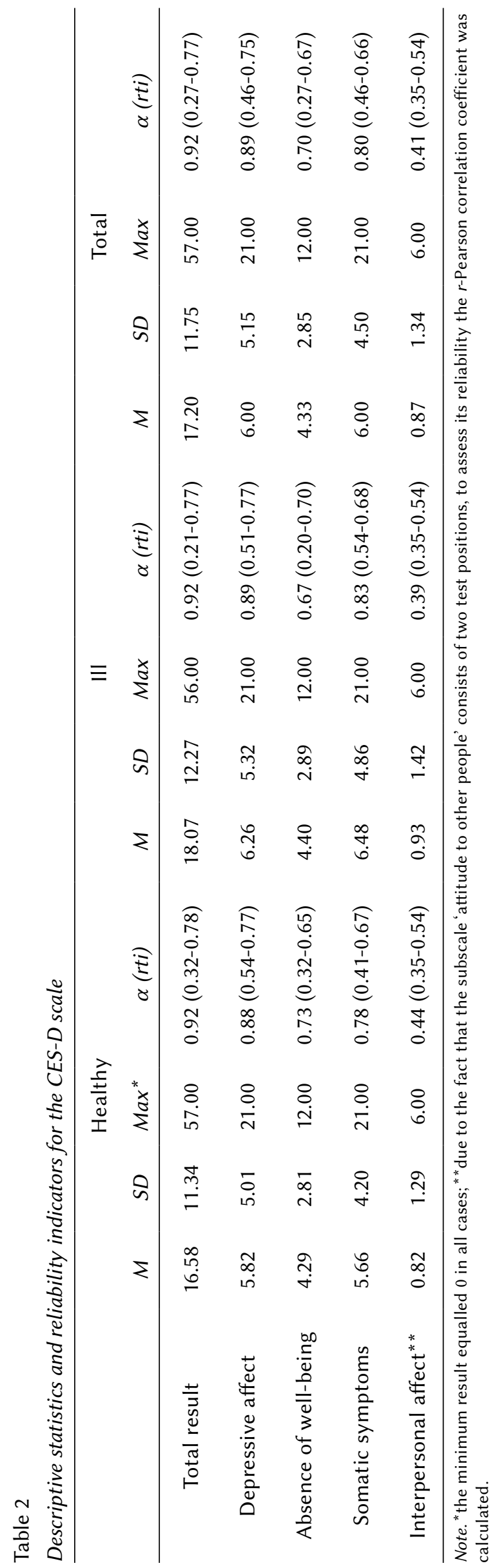

patients, $r=0.77, p<0.001$, and for the subgroup of healthy individuals, $r=0.62, p<0.001$. The stability of the subscales in the entire sample ranged from $r=0.50$ $(p<0.001)$ - subscale attitude to other people - to $r=$ $=0.70(p<0.001)-$ subscale depressive affect. For the subgroup of patients, stability indicators ranged from $r=0.57(p<0.001)-$ subscale attitude to other people to $r=0.74(p<0.001)-$ subscale depressive affect. However, in the subgroup of healthy individuals, these indicators reached lower values and ranged from $r=0.39$ $(p<0.001)$ - subscale attitude to other people to $r=0.61$ $(p<0.001)$ - subscale lack of positive affect.

Internal consistency. The Cronbach $\alpha$ coefficient was calculated in order to estimate the internal consistency of the method. For the results obtained for the whole scale by the ill, the healthy and by the whole sample, $\alpha=0.92$. The most reliable was the depressive affect subscale. Reliability coefficients calculated for the entire sample were at the level of $\alpha=0.88$, and in the subgroups of healthy and ill individuals the coefficient equalled the same $-\alpha=0.89$. The least reliable was the attitude to other people subscale. The strength of the relation between its positions were as follows: for the entire scale $r=0.41$; for ill individuals $r=0.39$; and for healthy individuals $r=0.44$. Of note, because this subscale consists of two items, the $r$-Pearson correlation coefficient was calculated between them as an indicator of internal consistency.

Correlations between CES-D subscales are presented in Table 3. The analysis was conducted separately for the healthy and for the ill subjects. The calculated correlation coefficients were high, with the exception of the relation between the positive affect subscale and the attitude to other people subscale, the strength of which was average. The results of subsequent subscales correlate with the overall scale result in the interval from 0.59 to 0.94 in the subgroup of healthy individuals and from 0.60 to 0.94 in the subgroup of ill individuals. The direction of the relationship in the group of ill and healthy individuals was identical, and its strength similar. In the case of no correlation there was a difference larger than 0.1 in the strength of the relationship. The subscale somatic symptoms in the group of ill individuals correlated strongest with the overall scale result $(r=0.91 ; p<0.01)$.

Criterion validity. Unhealthy individuals achieved a much higher overall scale result $\left(t_{(1688,945)}=2.758\right.$; $p=0.006 ; d=0.13)$ and the result in the somatic symptoms subscale $\left(t_{(3,949)}=3.949 ; p<0.001 ; d=0.18\right)$.

Gender differences were also revealed for the intensity of depression symptoms. Women had intensity of symptoms $\left(M_{K}=18.17 ; S D_{K}=12.10 ; M_{M}=15.03\right.$; $\left.S D_{M}=10.63 ; t=5.531 ; d f=1979 ; p<0.001 ; d=0.28\right)$. They achieved higher results in the depressive affect subscale $\left(M_{K}=6.55 ; S D_{K}=5.29 ; M_{M}=4.78 ; S D_{M}=4.6\right.$; $t=7.150 ; d f=1979 ; p<0.001 ; d=0.36)$ and the somatic symptoms subscale $\left(M_{K}=6.34 ; \mathrm{SDK}=4.60 ; M_{M}=5.24\right.$; $\left.S D_{M}=4.17 ; t=5.075 ; d f=1979 ; p<0.001 ; d=0.25\right)$. 


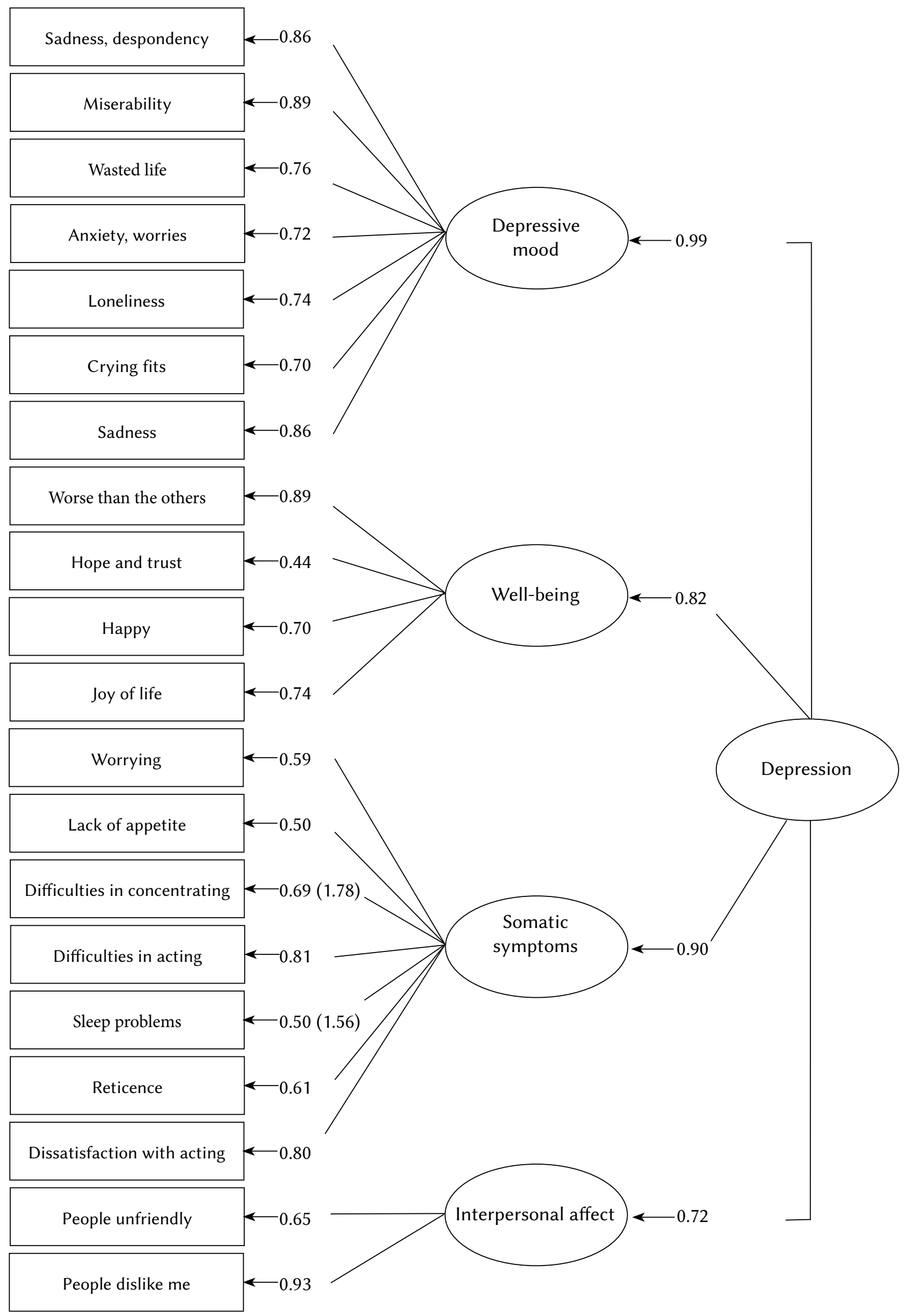

Figure 1. Structural and measurement model in the group of healthy individuals $(n=1160)$. 


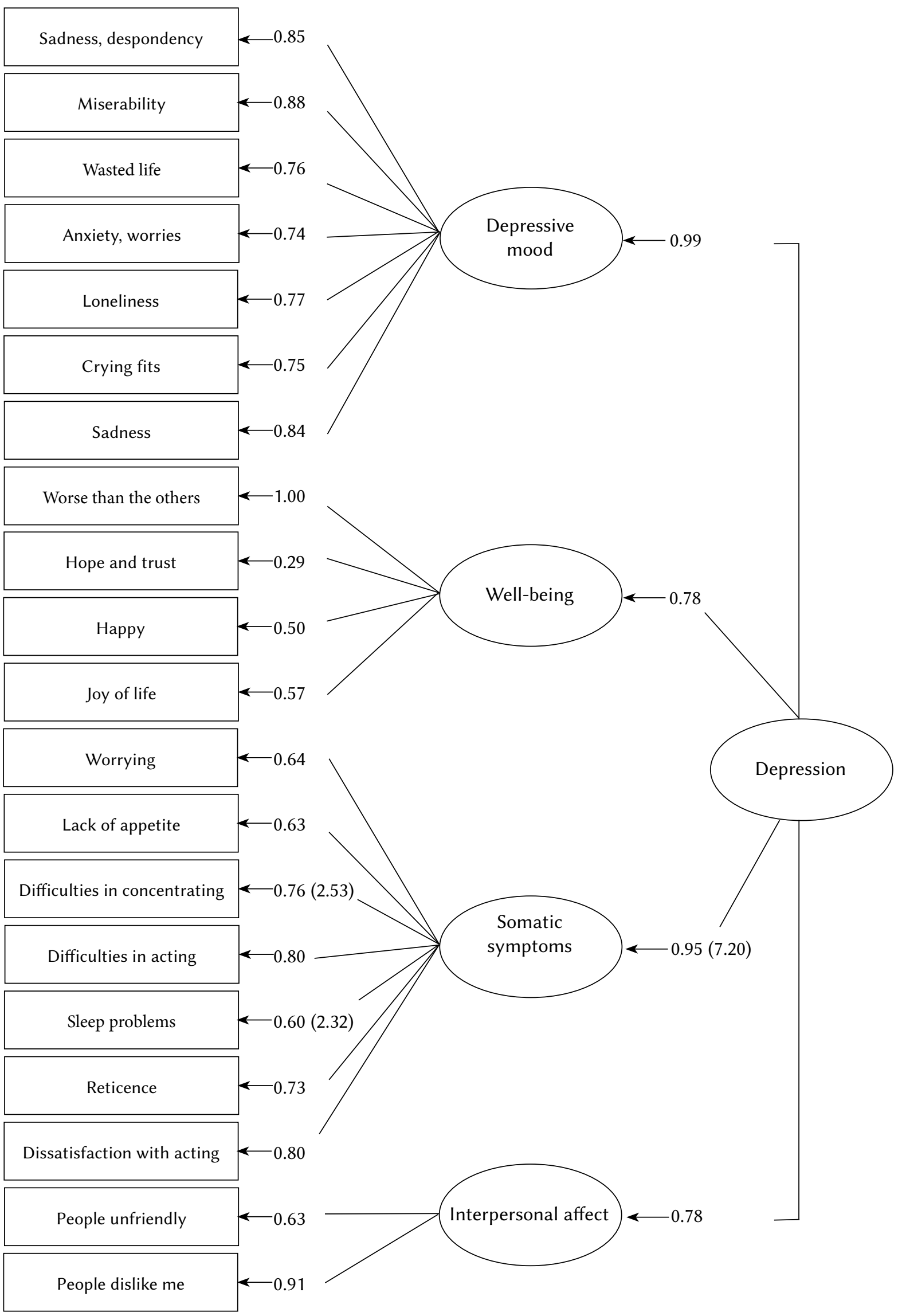

Figure 2. Structural and measurement model in the group of ill individuals $(n=826)$. 
The lack of positive affect and attitude to other people subscales did not differentiate between women and men. A positive correlation between age and depression severity was also observed $(r=0.07 ; p=0.002)$.

In order to assess the criterion validity of the tool, correlation analysis was conducted between the CES-D subscales and the measures of emotional functioning (the level of anxiety, satisfaction with life), resources (sense of coherence, sense of self-efficacy, social support, psychological resilience) and the degree of disease acceptance in the case of those respondents who suffered from chronic diseases (Table 4). The obtained correlation pattern was in line with the predictions, i.e. a high result in the depression scale and each of its subscales correlated positively with anxiety. The weakest relation was observed between the lack of positive affect subscale and the level of anxiety $(r=0.45$; $p<0.01)$. On the other hand, anxiety correlated strongest with the overall scale result $(r=0.68 ; p<0.01)$. The overall result of the scale and its subscales was inversely proportional to other measured variables. The value of correlation coefficients was moderate. The strongest relation was observed between the overall result and the sense of coherence $(r=-0.43 ; p<0.01)$, and the weakest - between the attitude to other people subscale and the sense of satisfaction with life $(r=-0.15$; $p<0.01$ ).

\section{CONCLUSIONS}

The aim of the study was to evaluate the psychometric properties of the Polish version of the Centre for
Epidemiological Studies Depression Scale (CES-D). The obtained results suggest that the scale structure is internally compliant with theoretical assumptions, it is internally consistent, and it has high criterion validity. The longitudinal study in the subgroups of ill and healthy individuals confirms the temporal stability of this psychometric tool. The CES-D scale seems to be a reliable tool to measure depression. Of note, all conclusions concerning the psychometric properties of the tool are preliminary because of the study sample characteristics. The sample was not representative in terms of its composition, age span and types of illnesses the patients suffered from. The socio-demographic differences were especially large between the groups of healthy and ill individuals.

The results of confirmatory factor analysis supported the existence of the four factors proposed by Radloff (1977). These were identified in the samples both of the ill and healthy individuals. This result is consistent with the observations made earlier in other populations and cultures (see Paterson et al., 2011; Hertzog et al., 1990; McCauley et al., 2006). The parameters of the theoretical model fit to the empirical data in both subgroups were similar. This observation suggests that the CES-D questionnaire can be used for screening and identifying individuals at risk of depression, regardless of whether or not they belong to the risk group. This thesis is supported by the fact that the results of analyses concerning reliability, stability and validity were similar in both samples. Some authors find CES-D useful in estimating the intensity of depressive symptoms in people affected by this disease (see Seligman et al., 2003; Al-Modallal,

Table 3

Correlations between the CES-D scales in the group of healthy and ill individuals

\begin{tabular}{cccc}
\hline Total result & $\begin{array}{c}\text { Depressive } \\
\text { affect }\end{array}$ & $\begin{array}{c}\text { Lack of positive } \\
\text { affect }\end{array}$ & $\begin{array}{c}\text { Somatic } \\
\text { symptoms }\end{array}$ \\
\hline
\end{tabular}

Depressive affect

$\begin{array}{ll}\text { Healthy } & 0.94^{* *} \\ \text { III } & 0.94^{* *}\end{array}$

Absence of well-being

\begin{tabular}{|c|c|c|}
\hline Healthy & $0.76^{\star *}$ & $0.64^{* *}$ \\
\hline III & $0.68^{* *}$ & $0.53^{* *}$ \\
\hline
\end{tabular}

Somatic symptoms

\begin{tabular}{|c|c|c|c|}
\hline Healthy & $0.89^{* *}$ & $0.76^{* *}$ & $0.52^{* *}$ \\
\hline III & $0.91^{* *}$ & $0.81^{* *}$ & $0.49^{* *}$ \\
\hline
\end{tabular}

Interpersonal affect

\begin{tabular}{cllll} 
Healthy & $0.59^{* *}$ & $0.51^{* *}$ & $0.36^{* *}$ & $0.45^{* *}$ \\
III & $0.60^{* *}$ & $0.53^{* *}$ & $0.27^{* *}$ & $0.49^{* *}$ \\
\hline
\end{tabular}


Table 4

Relations between depression and its dimensions, and anxiety and resources - r-Pearson correlation coefficient

\begin{tabular}{|c|c|c|c|c|c|}
\hline & $\begin{array}{l}\text { Total } \\
\text { result }\end{array}$ & $\begin{array}{c}\text { Depressive } \\
\text { effect }\end{array}$ & $\begin{array}{c}\text { Absence } \\
\text { of well- } \\
\text { being }\end{array}$ & $\begin{array}{l}\text { Somatic } \\
\text { symptoms }\end{array}$ & $\begin{array}{c}\text { Inter- } \\
\text { personal } \\
\text { affect }\end{array}$ \\
\hline $\begin{array}{l}\text { Tendency to habitual worrying } \\
\text { (anxiety) }\end{array}$ & $0.68^{* *}$ & $0.66^{* *}$ & $0.45^{* *}$ & $0.58^{* *}$ & $0.46^{* *}$ \\
\hline Sense of satisfaction with life & $-0.33^{* *}$ & $-0.28^{* *}$ & $-0.41^{* *}$ & $-0.25^{* *}$ & $-0.15^{* *}$ \\
\hline Social support & $-0.34^{* *}$ & $-0.28^{* *}$ & $-0.34^{* *}$ & $-0.28^{* *}$ & $-0.25^{* *}$ \\
\hline Sense of coherence & $-0.43^{* *}$ & $-0.39^{* *}$ & $-0.34^{* *}$ & $-0.38^{* *}$ & $-0.24^{* *}$ \\
\hline Psychological resilience & $-0.28^{* *}$ & $-0.23^{* *}$ & $-0.38^{* *}$ & $-0.19^{* *}$ & $-0.18^{* *}$ \\
\hline Sense of self-efficacy & $-0.36^{* *}$ & $-0.29^{* *}$ & $-0.37^{\star *}$ & $-0.25^{\star *}$ & $-0.16^{* *}$ \\
\hline Acceptance of the disease & $-0.36^{* *}$ & $-0.34^{\star *}$ & $-0.26^{* *}$ & $-0.33^{\star *}$ & $-0.16^{* *}$ \\
\hline
\end{tabular}

2010). However, the questionnaire also allows significant differentiation in the intensity of depressive symptoms in nonclinical populations (e.g. Kaczmarek et al., 2013; Seligman, Steen, Park \& Peterson, 2005).

The conducted analysis of the relationship between the CES-D scale and the measures of emotional functioning (anxiety, satisfaction with life), resources and social support yielded results in line with our expectations. The value of the correlation coefficients was moderate, which means that the variance value divided by these variables suggests their linkage while maintaining separateness.

This study is a preliminary evaluation of the psychometric properties of the Polish version of the CES-D scale and has some limitations. The most serious of these concerns the composition of the healthy and ill samples. The samples were not representative and do not allow the construction of norms for the whole population. Further studies should include patients with other chronic diseases, and other groups at risk of developing depression (such as adolescents). The population of healthy individuals should include the elderly, because relatively young people participated in this research project. The average age of healthy subjects was below 27 years. Further research on the properties of the CES-D scale is necessary to conduct complete evaluation of the psychometric properties of the Polish version of the questionnaire.

This research project was partially financed from the grant NCN 2011/01/B/HS6/00423 entitled 'Coping with a chronic illness - psychological conditions and consequences', carried out from 2011 to 2014 (grant holder Michat Ziarko) and NCN N106 291239 entitled 'Measuring changes in levels of happiness' (grant holder Łukasz D. Kaczmarek).

\section{ENDNOTES}

1 This part of the research was conducted under the grant NCN 2011/01/B/HS6/00423, entitled 'Coping with a chronic illness - psychological conditions and consequences', carried out from 2011 to 2014. Grant holder Michał Ziarko.

2This part of research was conducted under the grant NCN N106 291239, entitled 'Measuring changes in the level of happiness', carried out from 2010 to 2012. Grant holder Łukasz Kaczmarek.

\section{RefERENCES}

Affleck, G., Tennen, H., Urrows, S. \& Higgins, P. (1991). Individual differences in the day to day experience of chronic pain: a prospective d aily study of rheumatoid arthritis patients. Health Psychology, 10, 419-426. DOI: 10.1037/0278-6133.10.6.419.

Al-Modallal, H. (2010). Screening depressive symptoms in Jordanian women: evaluation of the Center for Epidemiologic Studies-Depression scale (CES-D). Issues in Mental Health Nursing, 8, 537544. DOI: 10.3109/01612841003703329.

Andresen, E.M., Malmgren, J.A., Carter, W.B. \& Patrick, D.L. (1994). Screening for depression in well older adults: Evaluation of a short form of the CES-D. American Journal of Preventive Medicine, 10, 77-84.

Antonovsky, A. (1995). Rozwikłanie tajemnicy zdrowia. Jak radzić sobie ze stresem i nie zachorować? [Unraveling the mystery of health - how people manage stress and stay well]. Warszawa: Wydawnictwo Fundacja IPN.

Aronen, E.T. \& Soininen, M. (2000). Childhood depressive symptoms predict psychiatric problems in 
young adults. The Canadian Journal of Psychiatry, 45, 465-470.

Block, J., Kremen, A.M. (1996). IQ and Ego-Resiliency: conceptual and empirical connections and separateness. Journal of Personality and Social Psychology, 70, 349-361. DOI: 10.1037/0022-3514.70.2.349.

Craig, T.J. \& van Natta, P.A. (1978). Recognition of depressed affect in hospitalized psychiatric patients: staff and patient perceptions. Diseases of the Nervous System, 10, 561-566.

Diener, E., Emmons, R.A., Larsen, R.J. \& Griffin, S. (1985). The Satisfaction With Life Scale. Journal of Personality \& Social Assessment, 49, 71-75.

Du Toit, M. \& Du Toit, S.H.C. (2001). Interactive LISREL: User's Guide. Lincolnwood, IL: Scientific Software International, Inc.

Felton, B.J., Revenson, T.A. \& Hinrichsen, G.A. (1984). Stress and coping in the explanation of psychological adjustment among chronically ill adults. Social Science \& Medicine, 18, 889-898.

Fifield, J., Mcquillan, J., Armeli, S., Tennen, H., Reisine, S. \& Affleck, G. (2004). Chronic strain, daily work stress and pain among workers with rheumatoid arthritis: Does job stress make a bad day worse? Work \& Stress, 4, 275-291. DOI: 10.1080/02678370412331324996.

Gärtner, G. (2006). Anforderungsbewältigung im aktuellen gesellschaftlichen Wandlungsprozess. Unpublished doctoral dissertation. University of Leipzig, Germany.

Hankin, B.L., Wetter, E. \& Cheely, C. (2008). Sex differences in child and adolescent depression: developmental psychopathological approach. In: J.R.Z. Abela \& B.L. Hankin (eds.). Handbook of depression in children and adolescents (p. 377-414). New York: Guilford Press.

Hertzog, C., Van Alstine, J., Usala, P.D., Hultsch, D.F. \& Dixon, R. (1990). Measurement properties of the Center for Epidemiologic Studies Depression Scale (CES-D) in older populations. Psychological Assessment, 2, 64-72. DOI: 10.1037/1040-3590.2.1.64

Hicks, A.D. \& McCord, D.M. (2012). Correlating the BDI-II, CES-D, and the Five-Factor Model: A Pilot Study. Individual Differences Research, 10, 27-36.

$\mathrm{Hu}$, L. \& Bentler, P. (1998). Fit indices in covariance structure modeling: sensitivity to underparameterized model misspecification. Psychological Methods, 4, 424-453.

Jöreskog, K.G. \& Sörbom, D. (2006). LISREL for Windows [Computer software]. Lincolnwood, IL: Scientific Software International.

Jöreskog, K.G. \& Sörbom, D. (1999). LISREL 8: User's Reference Guide. Lincolnwood, IL: Scientific Software International, Inc.

Juczyński, Z. (2001). Narzędzia pomiaru w promocji i psychologii zdrowia [Measurement tools in health promotion and health psychology]. Warszawa: Pracownia Testów Psychologicznych Polskiego Towarzystwa Psychologicznego.
Kaczmarek, Ł. (2011). Kwestionariusz Sprężystości Psychicznej - polska adaptacja Ego Resiliency Scale. Czasopismo Psychologiczne, 17, 263-265.

Kaczmarek, Ł.D. \& Aleszczyk, K. (2013). Mechanizm sprężystości psychicznej - model mediacji dwukrokowej z udziałem strategii radzenia sobie i pozytywnego afektu. Czasopismo Psychologiczne, 19, 67-72.

Kaczmarek, Ł.D., Kashdan, T.B., Kleiman, E., Bączkowski, B., Enko, B., Siebers, A., Szäefer, A., Król, M. \& Baran, B. (2013). Who self-initiates gratitude interventions in daily life? An examination of intentions, curiosity, depressive symptoms, and life satisfaction. Personality and Individual Differences, 55, 805-810.

Kaniasty, K. (2003). Klęska żywiołowa czy katastrofa spoteczna? Psychospoteczne konsekwencje polskiej powodzi 1997 roku [Natural or social catastrophy? Psychosocial consequences of 1997 flood in Poland]. Gdańsk: Gdańskie Wydawnictwo Psychologiczne.

Katz, P.P. \& Yelin, E.H. (1993). Prevalence and correlates of depressive symptoms among persons with rheumatoid arthritis. The Journal of Rheumatology, 20, 790-796.

Kessler, R.C., Avenevoli, S. \& Merikangas, K.R. (2001). Mood disorders in children and adolescents: An epidemiologic perspective. Biological Psychiatry, 49, 1002-1014.

Kim, G., DeCoster, J., Huang, C.H. \& Chiriboga, D.A. (2011). Race/ethnicity and the factor structure of the center for epidemiologic studies depression scale: a meta-analysis. Cultural Diversity and Ethnic Minority Psychology, 17, 381-396. DOI: 10.1037/ a0025434.

Lane, D., Carroll, D., Ring, C., Beeveres, D.G. \& Lip, G.Y.H. (2002). The prevalence and persistence of depression and anxiety following myocardial infarction. British Journal of Health Psychology, 7, 11-21.

Marsh, H., Hau, K. \& Wen, Z. (2004). Structural equation models of latent interactions: evaluation of alternative estimation strategies and indicator construction. Psychological Methods, 9, 275-300.

Maughan, B., Collishaw, S. \& Stringaris, A. (2013). Depression in childhood and adolescence. Journal of the Canadian Academy of Child and Adolescent Psychiatry, 22, 35-40.

McCauley, S.R., Pedroza, C., Brown, S.A., Boake, C., Levin, H.S., Goodman, H.S. \& Merritt, S.G. (2006). Confirmatory factor structure of the Center for Epidemiological Studies Depression scale (CES-D) in mild-to-moderate traumatic brain injury. Brain Injury, 20, 519-527. DOI:10.1080/02699050600676651.

National Institute of Mental Health (2009). The numbers count: Mental disorders in America. http:// www.nimh.nih.gov/health/publications/thenumbers-count-mental-disorders-in-america/index. shtml\#Mood 
Paterson T., O’Rourke N., Elmer E., Shapiro R.J. \& Thornton, W. (2011). The composition and structure of depressive symptomatology in renal disease. Canadian Journal of Behavioural Science, 43, 318-327.

Radloff, L.S. (1977). The CES-D Scale: A self-report depression scale for research in the general population. Applied Psychological Measurement, 1, 385-401.

Satorra, A. \& Bentler, P.M. (1988). Scaling corrections for statistics in covariance structure analysis. Los Angeles: University of California, Department of Psychology.

Schwarzer, R., Jerusalem, M. (1995). Generalized SelfEfficacy scale. In J. Weinman, S. Wright \& M. Johnston. Measures in health psychology: A user's portfolio. Causal and control beliefs (pp. 35-37). Windsor, UK: NFER-NELSON.

Seligman, M.E.P., Steen, T.A., Park, N. \& Peterson, C. (2005). Positive psychology progress. Empirical validation of interventions. American Psychologist, 60, 410-421.

Seligman, M.E.P., Walter, E.F. \& Rosenhan, D.L. (2003). Psychopatologia [Psychopathology]. Poznań: Wydawnictwo Zysk i S-ka.

Shafer, A.B. (2006). Meta-analysis of the factor structures of four depression questionnaires: Beck, CES-D, Hamilton, and Zung. Journal of Clinical Psychology, 62, 123-146. DOI:10.1002/jclp.20213.

Shaver, P.R. \& Brennan, K.A. (1991). Measures of Depression and Loneliness. In: J.P. Robinson, P.R. Shaver \& L.S. Wrightsman (eds.). Measures of Personality and Social Psychological Attitudes. $1^{\text {st }}$ Edition. Volume 1: Measures of Social Psychological Attitudes (p. 195-290). San Diego, Londyn: Elsevier.

Shnek, Z.M., Irvine, J., Stewart, D. \& Abbey, S. (2001). Psychological factors and depressive symptoms in ischemic heart disease. Health Psychology, 20, 141-145. DOI: 10.1037//0278-6133.20.2.141.

Thapar, A., Collishaw, S., Pine, D.S. \& Thapar, A.K. (2012). Depression in adolescence. Lancet, 9820, 1056-1067. DOI:10.1016/S0140-6736(11)60871-4.

Thomas, J.L. \& Brantley, P.J. (2004). Factor structure of the Center for Epidemiologic Studies Depression Scale in low-income women attending primary care clinics. European Journal of Psychological Assessment, 20, 106-115. DOI: 10.1027/1015-5759.20.2.106.

Uguz, F., Akman, C., Kucuksarac, S. \& Tufekci, O. (2009). Anti-tumor necrosis factor-a therapy is associated with less frequent mood and anxiety disorders in patients with rheumatoid arthritis. Psychiatry and Clinical Neurosciences, 63, 50-55. DOI: 10.1111/j.1440-1819.2008.01905.x.

Wells, A. (1994). A multi-dimensional measure of worry: Development and preliminary validation of the Anxious Thoughts Inventory. Anxiety, Stress \& Coping, 6, 289-299. DOI: 10.1080/10615809408248803.

Zautra, A.J., Parrish, B.P., Van Puymbroeck, C.M., Tennen, H., Davis, M.C., Reich, J.W. \& Irwin, M. (2007).
Depression history, stress, and pain in rheumatoid arthritis patients. Journal of Behavioral Medicine, 30, 187-197. DOI 10.1007/s10865-007-9097-4.

Zautra, A.J. \& Smith, B.W. (2001). Depression and reactivity to stress in older women with rheumatoid arthritis and osteoarthritis. Psychosomatic Medicine, 63, 687-696.

Zich, J.M., Attkisson, C.C. \& Greenfield, T.K. (1990). Screening for depression in primary care clinics: The CES-D and the BDI. International Journal of Psychiatry in Medicine, 20, 259-277. DOI:10.2190/ LYKR-7VHP-YJEM-MKM2. 